\title{
Variability of female gametophyte of tobacco in vivo and in vitro under the influence of extreme temperatures and its possible consequences \\ Lobanova L.P., Kolesova A.Yu.
}

Saratov National Research State University named after N.G. Chernyshevsky, Saratov, Russia

E-mail: lobanova-lp@yandex.ru

Key message. High and low temperatures induce the formation of abnormal embryo sacks (ES). ES with additional cells in the egg cell apparatus and synergids that are similar to an egg sells are capable of producing seeds with additional and haploid embrios.

Keywords: tobacco, in vitro, temperature, abnormally embryo sacs

The study of the variability of the female gametophyte contributes to the solution of many problems of genetics and selection related to issues of sterility, changes in the level of ploidy, the creation of homozygous forms, and the study of apomixis. The aim of the work was to study the possibility of reconstructing the structure of the female gametophyte by extreme temperatures and to assess the prospects for using the obtained modifications in cytological and genetic studies. The object was a homozygous line of tobacco BG-6. The embryo sacks were exposed to extremely low $\left(9-13^{\circ} \mathrm{C}\right)$ and high temperatures $\left(35-40^{\circ} \mathrm{C}\right)$ from the stage of mononuclear ES to mature. The studies of the temperature reaction were carried out under different conditions: in vitro (on the isolated ovaries) and in vivo (on plants in a thermal chamber, in a greenhouse and in a field). It was found that the same temperature effects in the different experimental conditions lead to the same violations of the structure of the ES. The differences are mainly quantitative. The different temperature conditions lead to the formation of the different types of abnormal ES. At low temperatures there are dominant ES with a halt in the development at 2-4 nuclear stages, but among 7-8 nuclear with a frequency of 4-9\% there occur the ES with synergids that are similar to egg sells. The greatest variety of types of abnormal ES was at high temperatures. An increase in the number of mitoses in gametogenesis leads to the formation of numerous 9-48-nuclear ES instead of 8-nuclear in the norm. At the temperature of $40^{\circ} \mathrm{C}$, cytokinesis is suppressed and coenocyte multinuclear ES dominate. At $37^{\circ} \mathrm{C}$ among the abnormal ones cellular ES with more than 8 nuclei dominate. In such sacks the additional cells in the egg apparatus with a frequency of 4-11\% are formed. The most of abnormal structure ES are sterile. In the ES with the synergids that are similar to the egg sells and additional cells in the egg apparatus the fertilization of 2-3 cells is possible. It is probably that additional embryos develop exactly in these ES, which is confirmed by the results of the seed germination. Twin plants - twins and triplets - were identified among the seedlings. A frequency of polyembryony was $0,1 \%$. Twin plants were diploid and haploid. Thus, the possibility of the implementation of the polyembryony and the haploidy on the basis of the induced variations of the structure ES is shown.

\section{Изменчивость женского гаметофита табака в условиях in vivo и in vitro под влиянием экстремальных температур и ее возможные последствия Лобанова Л.П., Колесова А.Ю.}

Саратовский национальный исследовательский государственный университет имени Н.Г. Чернышевского, Саратов, Россия

\begin{abstract}
Аннотация. Высокие и низкие температуры индуцируют образование аномальных зародышевых мешков (3М). 3М с дополнительными клетками в яйцевом аппарате и яйцеклеткоподобными синергидами способны к образованию семян с дополнительными и гаплоидными зародышами.
\end{abstract}

Ключевые слова: табак, in vitro, температура, аномальные зародышевые мешки

Изучение изменчивости женского гаметофита способствует решению многих задач генетики и селекции, связанных с вопросами стерильности, изменением уровня плоидности, созданием гомозиготных форм, изучением апомиксиса. Цель работы заключалась в изучении возможности реконструкции структуры женского гаметофита экстремальными температурами и оценке перспектив использования полученных модификаций в цитологических и генетических исследованиях. Объектом послужила гомозиготная линия табака БГ-6. Действию экстремально низких $\left(9-13^{\circ} \mathrm{C}\right)$ и высоких температур $\left(35-40^{\circ} \mathrm{C}\right)$ подвергались зародышевые мешки от стадии одноядерного ЗМ до зрелого. Исследования температурной реакции проводились в разных условиях: in vitro (на изолированных завязях) и in vivo (растениях в термокамере, оранжерее и поле). Установлено, что одинаковые температурные воздействия в разных экспериментальных условиях приводят к одинаковым нарушениям структуры ЗМ. Отличия носят в основном количественный характер. Различные температурные условия приводят к образованию разных типов аномальных ЗМ. При низких температурах доминируют 3М с остановкой развития на 2-4-ядерной стадиях, а среди 7-8-ядерных с частотой 4-9\% встречаются 3М с яйцеклеткоподобными синергидами. Наибольшее разнообразие типов аномальных ЗМ было при высоких температурах. Увеличение числа митозов в гаметогенезе приводит к образованию многочисленных 9-48-ядерных 3М вместо 8-ядерных в норме. При температуре $40^{\circ} \mathrm{C}$ подавляется цитокинез и доминируют ценоцитные многоядерные $3 \mathrm{M}$. При $37^{\circ} \mathrm{C}$ среди аномальных преобладают клеточные ЗМ с числом ядер более 8. В таких мешках с частотой 4-11\% образуются дополнительные клетки в яйцевом аппарате. Большинство ЗМ аномального строения стерильны. В $3 \mathrm{M} \mathrm{c}$ яйцеклеткоподобными синергидами и дополнительными клетками в яйцевом аппарате возможно оплодотворение 2-3 клеток. Вероятно, именно в этих ЗМ развиваются дополнительные зародыши, что подтверждается результатами проращивания семян. Среди проростков выявлены близнецовые растения - двойни и тройни. Частота полиэмбрионии составила $0,1 \%$. Близнецовые растения были диплоидными или гаплоидными. Таким образом, показана возможность реализации полиэмбрионии и гаплоидии на основе индуцированных вариаций структуры 3М. 